\title{
勧誘の場面で用いられる否定疑問文は \\ なぜポライトな表現になるのか \\ Why is the Use of the Negative Interrogative Regarded \\ as a Polite Way to Make an Invitation?
}

許 夏玲

東京学芸大学留学生センター

\section{要旨}

否定疑問文は初級の日本語学習で勧誘の表現として導入される。先行研究によれば、 日本語型の学習者（中国語、韓国語、タイ語）及び非日本語型の学習者（英語、 スペイン語、ポルトガル語、フランス語、ドイツ語）を対象に「肯定命題」と「否定 命題」の否定疑問文への応答について調査したところ、意味的に肯定に傾いている 「肯定命題」の否定疑問文は、日本語のレベルを問わず、習得が困難であるという 結果が得られている。本稿では中国語と英語の表現を参考にしながら、ポライトネス 理論の観点から勧誘で用いられる日本語の否定疑問文の真相を突き止め、異文化での 言語行動の接点を求めることを試みる。

キーワード：

否定疑問文、勧誘表現、日本語学習者、ポライトネス理論、話者意困 


\section{勧誘の場面で用いられる否定疑問文は \\ なぜポライトな表現になるのか}

許 夏玲

東京学芸大学留学生センター

\section{1. 研究動機}

否定疑問文では、命題内容を肯定と取る、いわゆる「肯定命題」と、命題内容を否 定とする、いわゆる「否定命題」の 2 つに分けられる（家村 1993）。たとえば、次の 例文を見てみよう。（下線は筆者によるもの）

(1)否定命題

（1）A：大学院には多いね。留学生。

B:ええ。そうですね。

$\mathrm{A}$ :でも学部生には、留学生っていないんですか?

B:いや、いらっしやいますよ。

（2）A：うそ、ほんとに全然聞いたことない?

B:いや、岡目だけなら聞いたことあるよ。でも八目って?

(2)肯定命題

（3）A：これ、それ、あれ、を教えるのに、どこか難しいところはありませんでしたか? B:いえ、あの、高校生の初級だったので、そこまでいきませんでした。

（4） A:服紗持ってこいっておっしやいませんでした?

B:いや、あのね、しばらくは何も持ってこなくていいって。

(家村 1993:83-84)

家村では、日本語型の学習者（中国語、韓国語、タイ語）及び非日本語型の学習者 （英語、スペイン語、ポルトガル語、フランス語、ドイツ語）を対象に「肯定命題」と 「否定命題」の否定疑問文への応答について調査したところ、意味的に肯定に傾いて いる上記(2)の「肯定命題」の否定疑問文は、日本語のレベルを問わず、習得が困難で あるという結果が得られた。その理由は、学習者は「否定疑問文の応答を、否定形式 だけで判断し、その他の要因を考慮できないことがうかがえる」（p.88）としている。 日常会話における勧誘や依頼の場面では、上記のような「肯定命題」の否定疑問文が よく用いられることから日本人の相手への配慮などを表すポライトな文化習慣の 一面が伺えるだろう。その使用の背景には、語用論の観点から適当な解釈が与え られるのではないかと思われる。 
日本人の勧誘表現については、ザトウラスキー(1993:1)の著書の動機で既にこう述べ られている。著者が日本人の友人たちに旅行へ誘われた時、「ポリーさんは論文で 忙しいから、行くのは大変でしょう」と言われたことにショックを受けたということ である。なぜなら、著者の文化圏ではこのような誘いの表現は相手が自発的に断る ように仕向ける時に用いられる表現だという。しかし、著者の友人たちはそういう 意図は持っていないのである。このように、外国人にとって日本人の言語行動が本来 の意図とは逆のものとして捉えられ、日本人の勧誘表現には特有の「ストラテジー」 が用いられているとザトウラスキーは見解を示している。

\section{2. 研究目的}

筆者は上述の先行研究の動機から、否定疑問文の中で「肯定」の意味に傾いている、 いわゆる「肯定命題」の否定疑問文に興味を持つようになり、勧誘の場面でなぜ これらの表現がよく用いられるのかを明らかにしたいと考えるようになった。これら の表現の使用には会話の状況や話し手の意図、聞き手との関わりを抜きにしては語れ ないと考えている。本稿では中国語と英語の表現を参考にしながら、語用論の観点 から勧誘で用いられる日本語の否定疑問文の真相を突き止め、異文化での言語行動の 接点を求めることを試みる。

\section{3. 否定疑問文について}

日常、われわれは常に情報のやりとりを行っている。安達(1999)では、「情報を 聞き手に与えること」を「平叙文」、「情報を聞き手から得ること」を「疑問文」に よって実現するとしている。安達によると、真偽疑問文は話し手がある命題の真偽に ついて判断を保留することを前提にして問うのに対し、「傾き (bias)」を持つ疑問文は ある命題の真偽に対して話し手がある方向への傾きを含意して問うのである。

安達では、「傾き」を持つ否定疑問文は、聞き手から情報を得るという疑問文の 本来の機能から離れて、情報を聞き手に与えるといった平叙文的な機能に移行すると 見なしている。たとえば、次の (5) はその例である。

（5）「君は心配しなくていいよ。二、三日のうちに、お父さんとじっくり そのことを話すから」

「ね、あなた、無理してない?」（「「無理している」と思う）

「いや無理はしてないつもりだよ。ごめん、もう行かなきや」

（安達 1999:24-25） 


\section{勧誘の場面で用いられる否定疑問文は \\ なぜポライトな表現になるのか}

上記のような「傾き」を持つ否定疑問文は、「ている」の付加によって状態化 された述語を取っている場合、「のではないか」で言い換えることも可能である という。

(5’)「ね、あなた、無理してるんじやない?」

$(\rightarrow 「$ 無理している」と思う $)$

（5’）の場合、話し手が現実の諸々の事態から相手が「無理している」ということを 想定して聞き手に問いかけていると解釈できるのである。

しかし、次の (6)の勧誘や依頼のような場面で用いられている意志動詞の述語の場合、 ある判断（「相手が明日あたり飲みに行く」という「肯定命題」）への「傾き」を 持った文（「明日あたり飲みに行く」と思う）として解釈できないと安達は見なして いる。

（6）「明日あたり飲みに行きませんか？」（安達 1999:63）

なぜならば、前述の (6) では、「明日あたり飲みに行くんじやありませんか?」の ように、話し手が「のではないか」を用いて問いかけると、勧誘の意図と違った使用 状況（現実が「明日あたり飲みに行く」という既定事実と対立している場合の確認） になってしまうからである。

しかし、勧誘とは、通常話し手は相手に「飲みに行ってほしい」、つまり「飲みに 行くだろう」ということを前提に相手へ誘いかけることから「相手が明日あたり飲み に行く」という「肯定命題」への「傾き」を持った文として解釈できると筆者は考え ている。

たとえば、ここで日常の否定疑問文の用例を見てみよう。

（7）「年齢を重ねてもずっと美しくありたいと思いませんか? 頭から足の先まで ぬかりなく、試してもらいたいアイテムや対策をご紹介します。」

(http://www.yahoo.co.jp 2016.7.27)

（8）「60 歳からの暮らし見直してみませんか? 700 名規模の元気なシニアが集まって 暮らすコミュニティ。日々の食事サービスと生きがいや趣味を楽しむセカンド ライフ。介護施設とは違ういきいきとした健康的な暮らしが広がっています。」

(朝日新聞 2016.8.1) 
上記の否定疑問文の後の文章を見ると、筆者は否定疑問文を用いているが、命題を 肯定的に（「年齢を重ねてもずっと美しくありたいと思うこと」「60 歳からの暮らし 見直してみること」）捉えていることがわかる。ここで筆者が自分の肯定的に捉えて いる命題内容が読者の考えと一致していないかを確認していることが理解できる。

\section{4. 命題内容に対する確信度}

前述の先行研究をふまえて、もう一度整理してみると、次のように述べることが できる。ここでまずいくつかの疑問文を用いて互いの違いを見てみよう。

（9）映画を見に行きますか。

（9’）［命題 [映画を見に行く］+ 疑問］

（10）映画を見に行きませんか。

（10’）［[命題［映画を見に行く］+否定］+疑問］

上記の (9) では、話し手が「映画を見に行く」という命題内容が真実と一致しているか （「行く」こと）、そうでなければ、その反対となり、一致していない（「行かない」 こと）、いわゆる真偽を判断するために相手に問いかけていると見られる。

（9）に対し、（10）は話し手が勧誘という意図を持っていれば、当然「相手に映画を 見に行ってほしい」という願望のもとで相手が「映画を見に行く」ということを前提 に想定している。そこで、話し手があえて相手に命題内容が真実と一致していないか （「行かない」こと）を問いかけるということは、「真でなければ偽」「偽でなければ真」 という概念の下で、命題内容が真実と一致している（「相手が映画を見に行く」） ことがあくまでも話し手の物事への捉え方、いわば話し手の想定であって、現実には 「ひょっとすると行かない」という不安の要素を取り除くために相手に問いかけ、確定 させなければならないのである。言わば、（10）は相手の意志への確認と解釈できると 考えられる。

初級学習者向けの日本語教科書『はじめのいっぽ』（1995）では、「じや、いっしょ に映画を見に行きませんか」（p.111）、「『アラジン』を見に行きませんか」（p.113）の ような「〜ませんか」の勧誘表現が導入され、その発話意味を“ Shall we go and see a film together? ”、“ What do you think of seeing Aladdin with me? ” に英訳されていることが わかった。

また、Brown \& Levinson(1987)の日本語訳の著書(田中監訳 2011:167)では、以下の ような「〜ませんか」の訳例が挙げられている。 


\section{勧誘の場面で用いられる否定疑問文は \\ なぜポライトな表現になるのか}

(11) Do you want to $\{$ come / go $\}$ with me to the movie? 私と一緒に映画に \{来ませんか / 行きませんか。\}

前述の日英語の勧誘場面において、英語では話し手が真偽疑問文を用いて相手に ある命題が真実（現実とも言える）と一致しているかどうかを問うのに対し、日本語 では話し手が否定疑問文を用いて、相手の意志が話し手の捉えている「真実」（誘い に応じること）と対立していないかを確認するということから、日本語母語話者が 勧誘の際、命題を真（「一緒に何かをすること」）と捉え、命題に対する確信度が 真偽疑問文を用いるより高いと見られる。

\section{5. 語用論に基づく解釈}

\section{1 ポライトネス・ストラテジー}

Brown \& Levinson (1987) では人間の持つポジティブフェイス (自己イメージが他者に 評価され、好ましく思われたいという積極的な欲求）とネガティブフェイス（個人的 領域一他者に立ち入られたくないという消極的な欲求）の二つのフェイスを配慮に 入れ、依頼や要求の場面において、「あからさまに言う (Bold on record)」（「誰か、 助けて!」のように、緊急性のある場面で意図明示的に、かつ直接的な言語表現を 用いる)、「ポジティブポライトネス・ストラテジー(Positive politeness strategy)」 (「田中君、これ、コピーしてくれる?」のように、相手のポジティブフェイスを配慮 し、呼びかけ表現を用いて相手との仲間意識を高めるような意困明示的表現を用いる）、 「ネガティブポライトネス・ストラテジー(Negative politeness strategy)」（「ちょっと コピーをお願いしたいんですが…」のように、相手のネガティブフェイスを考慮し、 意図明示的な表現を用いるが、最終的な決定権は相手に委ねる）、「ぼやかしの表現を 使う (Off record)」（「もうすぐゼミが始まるんだけど、レジュメを早くコピーしなく ちゃ‥」ように、相手にヒントを提示して意図非明示的に働きかける表現を用いる） と「FTA を行わない(Do no FTA [Face Threatening Act])」（相手に依頼しない）の 五つのストラテジーの選択肢が設けられた。招待や勧誘の場合でも相手が利益を受ける とは言うものの、話し手が自分の要求に相手に応じてほしいと願っていることから 依頼や要求と似ていると考えられる。

では、勧誘や依頼の場面でよく用いられる「〜ませんか」をポライトネスの観点から 見てみよう。「〜ませんか」の勧誘表現は、「（一緒に）〜ましょうか」「〜ましょう」と 比べ、「束縛されたくない、私的領域に立ち入られたくない」という相手のネガティブ フィエスを配慮する面において、確かに消極的な表現になる。また、「映画を見に 行きませんか」、「コーヒーでも飲みに行きませんか」、「パーティーに行きませんか」 などの極一般的な勧誘表現の使用は、話し手の相手への誘いの意図を明示的に示して いることからネガティブポライトネス・スラトテジーの一手段であると言えよう。 
それは、「映画を見に行こうか」「映画を見に行こう」などのポジティブポライトネス・ ストラテジーの表現より「映画を見に行かない?」などの表現のほうが控えめになる ことがわかる。また、相手の意向が全然わからない、もしくは相手とそれほど親しく ない場合なら「映画のチケットがあるんだけど…」などの「ぼやかしの表現」が選ばれ やすいのだろう。

Brown \& Levinson で「疑問文・ぼかし語句（Question, hedge）」一つとして英語の 「付加疑問 (tags)」が取り上げられている。日本語の終助詞「ね」はこれに相当する 機能を有しているという。たとえば、(12) はその例である。

(12) \{ Do me a favour, / Take this out, \} will you?

(Brown \& Levinson 1987:147)

上記の「付加疑問」はネガティブポライトネス・ストラテジーの一つとされている。 話し手が同意を求める形で自分の提示した要求に対して最終的な判断を相手に委ねる ことから相手のネガティブフェイスを配慮したポライトな表現とされる。

英語の「付加疑問」に相当する日本語の表現には、日本語の終助詞の「ね」のほか、 「ではないか」もある。例えば、「いいじやないか」、「そんこと言ったってしょうが ないじゃないか」のような否定疑問文は、“It’s alright, isn’t it?”、“It can’t be helped to say that, can you?”のように付加疑問が用いられる。

勧誘の問いかけへの応答から見ると、勧誘に用いられる否定疑問文の特徵が うかがえる。次の筆者の作例 (13)、（14）と (15)を見てみよう。

（13）A：納豆は好きですか。

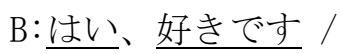

いいえ、好きではありません。

（14） A:近くでちょっとコーヒーでも飲みませんか。

B：ええ、いいですね。/（=ええ、飲みましょう）

いや、ちょっと急いでるので... （=いや、飲みません）

（15）A：そろそろ夕食を召し上がりませんか。

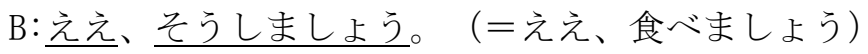

いや、まだ揃っていないから、もう少し待ちましょう。

（=いや、まだ食べません）

上記の (14) と (15) の否定疑問文の応答は (13)の真偽疑問文の応答と異なることが わかる。一見すると、命題内容を否定の形で問いかけているように聞こえるが、むしろ 話し手が「コーヒーを飲みますよね」「夕食を召し上がりますね」のように命題内容を 肯定の形（「コーヒーを飲む」「夕食を召し上がる」）で想定して相手に問いかけて いることがわかる。そこで、相手が否定の応答を返すのに理由を取り上げて説明する ことが特徵的である。 


\section{勧誘の場面で用いられる否定疑問文は \\ なぜポライトな表現になるのか}

なぜ否定の形で問いかけるかと言えば、真偽を問うような疑問文は話し手が「肯定」 も「否定」も両方の情報を把握できていないため、相手に問いかけるのに対し、勧誘 や依頼や要求の場合は、話し手が「相手が自分の思う通りに行動に応じてくれる」と 願っていることから当然「命題内容」を肯定的に取り、残りの「ひょっとしてそうし ないことはないよね」という未知の事態への不安を取り除くために確認の調子で相手 に問いかけるのである。そこで、相手も話し手の「肯定命題」の発話意図を察し、 応答している（たとえば、「ええ、いいですね。そうしましょう」）と考えられる。

日常の場面で買い物客がカードを持っているようだが、すぐ提示していない場合に、 店員が「Tーポイントカードをお持ちでないでしょうか」と確認するように、話し手が 命題内容を「肯定的」に取るか、「否定的」に取るか、否定疑問文のみを見ると判断 しかねるため、会話参加者の共有認識や会話のコンテクストにより否定疑問文を用いた 話者の意図や発話の真意が理解できると考えられる。

\section{2 中国語と英語の表現との対照比較}

日本語では、英語の付加疑問（tag question）（“don’t you”，“won’t you”など）に 相当する表現に終助詞の「ね」「よね」が用いられている。中国語では英語のような 付加疑問と似た意味を文末に「是吗?」などを用いて表すことがある。英語の付加 疑問は話し手が自分の話に対して相手に「こういう意味ですか」「これが正しいですか」 と確認を取るのに用いられる。たとえば、（16）を見てみよう。

（16a）You will go with us, won’t you?（あなたも一緒に行きますよね）

（16b） 你也去，是吗?（/是吧? ）

上記の付加疑問は、日常会話において発話の冒頭に来ることもある。次の(17) は その例である。

（17a） Won’t you go with us?（一緒に行きますよね）

（17b）＊不去吗?（/*不去吧?）

前掲の (16b) の中国語の付加疑問なら自然な文とされるが、（17b）にすると、「反論」 の意味になってしまう。話し手が「相手が一緒に行かない」ことを前提として相手に 確認し、その理由を問いかけていると考えられる。英語の発話の意味 (“You must go with us”）から考えると、意味的にはむしろ「你一定要去呀」のような積極的に相手を 誘う表現になる。

（16）と（17）のような勧誘表現は、ポライトネスの観点から解釈が得られると思 われる。井出(2006) では、英語母語話者がお客にケーキを勧める言い方として以下の 三つの表現の中で $(18 c)$ が、一番思いやりがあり、丁寧な言い方であると考えていると 述べられている。 
(18a) "You may have some of this cake."

(18b) "You should have some of this cake."

(18c) "You must have some of this cake."

(井出 2006:66)

その理由として、話し手が自分の作ったケーキをぜひ相手に食べてほしいという 気持ちを込めて勧めるため、「してもよい」の may が一見丁寧に聞こえる表現だが、 強く勧める must を使ったほうがむしろ相手に対しての思いやり、いわばポライトな 配慮になるからである。

\section{6. 勧誘の「〜ませんか」に見るポライトネス}

Brown \& Levinson（1987:122）では、否定疑問文の機能を “Negative questions, which presume 'yes' as an answer, are widely used as a way to indicate that $\mathrm{S}$ knows H's wants, tastes, habits, etc., and thus partially to redress the imposition of FTAs (Face Threatening Acts).” と している。これはポジティブポライトネス・ストラテジーの「前提操作 (presupposition manipulations）」（田中 監訳 2011）の一つであり、話し手が相手の願望、好み、習慣 などについて知っていることから仲間意識を示すのに否定疑問文を用いられると考え られる。

以下、Brown \& Levinson(1987)の日本語訳の著書(田中 監訳 2011:168)では、英語の 否定疑問文の例文を日本語の「〜ませんか」の否定疑問文に訳されている。勧めの 場面には次のよう(19) (20) が挙げられている。

（19）Wouldn’t you like a drink?（飲み物はいりませんか。）

（20）Don’t you want some dinner now?（そろそろ夕食を召し上がりませんか。）

また、意見を言う場面には次の(21) (22) が挙げられている。

（21） Don’t you think it’s marvelous!?（素晴らしいと思いませんか。）

（22） Isn’t it a beautiful day?（素晴らしいお天気じやありませんか。）

一方、上記の (21) (22) と次の (23)の文の違いについて見てみよう。

（23） It was amazing, wasn’t it?（すごかったですね！）（田中 監訳 2011:201） 


\section{勧誘の場面で用いられる否定疑問文は \\ なぜポライトな表現になるのか}

Brown \& Levinson では、(21)、（22）はポジティブポライトネス・ストラテジーの 「前提の操作 (presupposition manipulations)」としているのに対し、（23）はネガティブ ポライトネス・ストラテジーの「発話内効力のぼかし表現 (hedges on illocutionary force）」としている。（23）の使用背景として、話し手は聞き手が話し手の望んでいる 行為（「すごかったという意見に同意すること」）を行いたい、または行えることを 想定しない、強いて言えば、ある程度、聞き手の欲求（どう思うかということ）に ついて最小限に想定する（否定疑問文で反応を問いかける）ことに起因していると 考えられる。

勧誘の場合は、本来話し手の欲求を満たしているため、話し手側に利益が得られる という点では依頼や要求と共通しているが、勧誘の相手となる聞き手側にも利益が 得られる場合があるため、互恵の観点から依頼や要求と比べて聞き手側への負担度は 同等ではないと考えられる。また、もし話し手が、勧誘の相手が話し手の欲求通りに やりそうにもないことを想定しているのなら、相手に問いかけることもないだろう。 真偽疑問文では話し手が、命題内容が真実と一致しているから゙うかを相手に問いかけて 情報を求めるのに対し、勧誘に用いられる否定疑問文では、話し手側で当然ながら 命題内容を真（「相手が自分の思う通りの行動を取る」）であると捉えているのだが、 これがあくまでも話し手の想定であって、最終的な決定権が相手側にあるため、事実 と一致していないという未知の事態への不安の要素を相手への確認により確定させる と考えられる。

Brown \& Levinson（1987:230）で英語の付加疑問文についても次のように示唆をした。

“ When token tag questions are tacked on to a presumptuous positively polite request, for example, or when hedges (e.g. like, sort of) are used to render more vague the expression of an extreme positive-politeness opinion, the results are basically still positive-politeness strategies, even though they make use of essentially negative-politeness techniques to soften the presumption.”

勧誘に用いられる否定疑問文も同様に、「コーヒーを飲みに行こう」「コーヒーを 飲みに行きましょうか」のような直接的な言語表現（「話し手と聞き手は協力者で あることを伝える - 両者ともに活動に含める (Convey that S and H are cooperators: Include both S and H in the activity)」）より相手への興味や理解を示した上で、相手に 最終的な決定権を委ねるという「ぼかし表現」を用いたほうが丁寧に聞こえるので ある。しかし一方、話し手が命題内容を肯定的に捉えて相手に勧めることから仲間 意識、相手への思いやりを示すという点では、Brown \& Levinson で述べられている ポジティブポライトネス・ストラテジーの一手段であるのではないだろうか。 


\section{7. まとめと今後の課題}

勧誘の場面で用いられる否定疑問文について、筆者は次のように考える。「真で なければ偽」「偽でなければ真」という概念の下で、話し手が、命題内容を肯定的に （たとえば、「相手が映画を見に行く」）捉えているということは、あくまでも話し手の 物事への捉え方、いわば話し手の想定であって、現実には「ひょっとすると行かない」 という不安の要素を取り除くために相手に問いかけ、確定させなければならないので ある。言わば、相手の意志への確認と解釈できると考えられる。

なお、勧誘に用いられる否定疑問文は、「コーヒーを飲みに行こう」「コーヒーを 飲みに行きましょうか」のような直接的な言語表現より相手への興味や理解を示した 上で、相手に最終的な決定権を委ねるという「ぼかし表現」を用いたほうが丁寧に 聞こえるのである。しかし一方、話し手が命題内容を肯定的に捉えて相手に勧める ことから仲間意識、相手への思いやりを示すという点では Brown \& Levinson で述べ られているポジティブポライトネス・ストラテジーの一つであると考えられる。

以上のことから、勧誘の場面では、日本語母語話者は否定疑問文を用いて相手の 意志が話し手の捉えている「真実」と対立していないかを確認するという言語行動に 対し、中国語母語話者や英語母語話者は真偽疑問文を用いて相手の受諾の意志の 有無を問うという言語行動の相違がうかがえる。今後、更に依頼の場面で用いられる 日本語、中国語、英語の表現の比較対照を通して、語用論の観点から研究を深めて いきたい。

本稿は、2016 年の社会言語科学会第 37 回研究大会にて発表した内容をもとに修正、 加筆したものである。

\section{参考文献}

安達太郎（1999）『日本語疑問文における判断の諸相』くろしお出版

家村伸子（1993）「日本語否定疑問文の応答に関する中間言語研究」『日本語教育』81 号, 日本語 教育学会, pp.81-92

井出祥子（2006）『わきまえの語用論』大修館書店

ポリー・ザトラウスキー（1993）『日本語の談話の構造分析-勧誘ストラテジーの考察』くろしお 出版

Brown \& Levinson (1987) Politeness: Some Universals in Language Usage Cambridge

（田中典子 監修（2011）『ポライトネス 言語使用における、ある普遍現象』 研究社） 